\title{
Audacious bid to value the planet whips up a storm
}

One of the most controversial recent attempts to integrate economics and ecology has been a calculation, published last year by ecologist Robert Costanza of the University of Maryland and 12 co-authors, of a monetary value for the world's "ecosystem services and natural capital” (see Nature 387, 253-260; 1997). Such services include the purification of air and water, the mitigation of floods and drought, pollination, pest control, and the generation of fertile soils.

The idea of valuing ecosystem services was not new. Earlier in the year, the Stanford ecologist Gretchen Daily had published an edited volume, Nature's Services, containing contributions that aimed to "identify and characterize components of ecosystem value". But Costanza et al. did something that has been described as both "heroic" and "foolhardy": they tried to estimate the total value of all the world's ecosystem services. The answer was \$33 trillion per year: a figure that exceeds the sum of the world's gross national products.

The paper was a box-office success but was panned by the critics. It was widely covered by newspapers and magazines, and the $\$ 33$ trillion a year total has been quoted in public speeches by government officials. But many economists characterized the paper as not just wrong but misleading.

Costanza and his colleagues have been resolute in defending the importance of their contribution. And, as the dust settles, it seems that most interested observers believe that a paper with serious technical flaws has still served a useful purpose by drawing attention to an important issue.

\section{Valuing ecosystems}

At first glance, what Costanza et al. set out to do seems straightforward: namely to rectify the fact that "because ecosystem services are not fully 'captured' in commercial markets or adequately quantified, they are often given too little weight in policy decisions".

The paper describes $\$ 33$ trillion per year as "a minimum estimate" for the "current economic value" of 17 ecosystem services (from atmospheric gas regulation to the provision of "cultural value") summed over 16 types of ecosystem, or 'biomes' (from the open ocean to urban centres).

Mainstream economists were quick to protest. In a special issue of Ecological Economics devoted to the paper, Michael Toman of Resources for the Future called the $\$ 33$ trillion figure "a serious underestimate of infinity". A group of British economists wrote that the biome-scale calculations "risk ridicule from both scientists and economists", and called the figure "not supportable".
Economists complained that Costanza et al. didn't properly understand what they were doing. "If you use an economist's definition of valuation, you have to understand what it can be used for and what it can't," says Nancy Bockstael of the University of Maryland.

For neoclassical economists, value can be measured only in the context of a specific exchange. In this view, it is nonsensical to ask "the value" of the world's ecosystem services; an economist would ask, "value to whom?". A related requirement is that one can evaluate only small (or 'marginal') changes from current conditions. Real-world decisions are incremental:we may have to decide what it's worth to give up a hectare of beach, but we are never asked to give up all the beaches in the world.

\section{Local difficulties}

Costanza et al., critics complained, strayed out of context by taking valuations of particular ecosystem services, made in specific parts of the world, and converting these to "per hectare" values for a particular biome. For example, they used values placed on soil formation in Colorado as the basis of a calculation for all the world's grasslands. But this assumes that all hectares of grassland are equivalent - not only in their ability to form soil, but in the value of this service to local populations.

The critics also pointed out that, because the value of a commodity increases as it becomes more scarce, one cannot simply multiply the present value of a hectare of biome (even if there were a uniform value per hectare) by the number of hectares to get the total value. The last hectare to disappear will be much more valuable than the first.

In response, Costanza et al. argue that what they have done is no different from classical GNP accounting, in which "the total value of marketed products" is computed by multiplying the current price for each product by the number of units traded in a year. But the critics remain unpersuaded.

Costanza treats the detailed criticisms with some impatience, describing himself as a "big picture" person. "This is an order of magnitude study, a first cut," he says. "Probably most economists would have guessed 1 per cent of GNP or less [for the value of ecosystem services]. They're in the wrong order of magnitude. Therefore this issue requires a lot more attention."

One of Costanza's economist coauthors, Stephen Farber, of the Graduate School of Public and International Affairs at the University of Pittsburgh, admits that many of his fellow economists' criticisms are on target. "I don't place a lot of credibility on the $\$ 33$ trillion figure," he says. "But if we were to try to satisfy [our critics in neoclassical economics], doomsday would be past before we got any useful knowledge out there."

This seems to be the nub of the difference between Costanza et al. and their critics. The authors accept that what they did was imperfect in many ways, but feel strongly that their number is better than no number at all.

Ironically, "the number" has come back to haunt one of the economist co-authors. Ralph d'Arge, an emeritus professor from the University of Wyoming, says that he has had "calls from federal agencies asking how they can use this number to implement policy. The answer is that they can't; the per hectare numbers are average - they are unlikely to be a good measure of a local loss." D'Arge nevertheless stands by the paper's methods, saying "we followed all the rules [of neoclassical economics]".

While vocal critics such as Nancy Bockstael view the paper as potentially damaging to their profession, other economists are prepared to take a more philosophical view of its contribution. Trudy Cameron, for example, an environmental economist at the University of California at Los Angeles, characterizes Costanza et al.'s paper as "a recklessly heroic attempt to do something that's futile". But then she goes on to say that the paper has been "very useful - it has stirred things up a lot".

Michael Toman, one of the harshest critics of the paper's methods, echoes this view, saying that "it can best be read as a political document". Farber agrees that its main contribution has been in raising awareness of the issues it highlights. "We thought we would provoke, and thought that provocation would be good."

Indeed, the paper's most lasting contribution may be as a recruiting document. "Because of the paper we're seeing young graduate students becoming attached to this issue," says Farber. "Even if people tear the article apart, that's okay if it provokes interest in largescale problems."

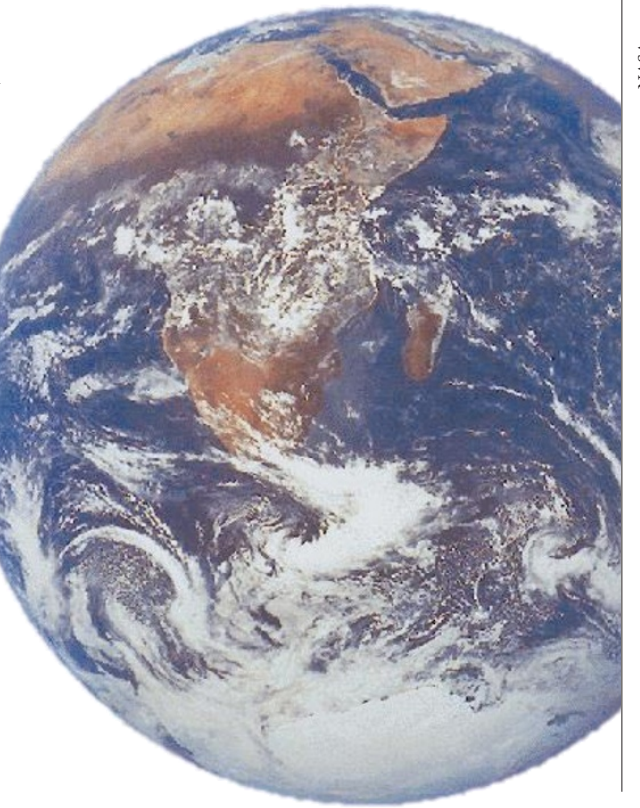

NATURE |VOL 395| 1 OCTOBER 1998 |www.nature.com 